\title{
New Compounds and Phase Selection of Nickel Sulfides via Oxidation State Control in Molten Hydroxides
}

\author{
Xiuquan Zhou, ${ }^{1}$ David J. Mandia, ${ }^{1}$ Hyowon Park, ${ }^{2}$ Mahalingam Balasubramanian, ${ }^{3}$ Lei Yu, ${ }^{4}$ \\ Jianguo Wen, ${ }^{5}$ Andrey Yakovenko, ${ }^{6}$ Duck Young Chung, ${ }^{1}$ and Mercouri G. Kanatzidis*, ${ }^{1,7}$ \\ 1. Materials Science Division, Argonne National Laboratory, 9700 South Cass Avenue, Lemont, IL 60439, USA \\ 2. Department of Physics, University of Illinois at Chicago, Chicago, Illinois 60607, USA \\ 3. X-ray Science Division, Advanced Photon Source, Argonne National Laboratory, Argonne, Illinois 60439, USA \\ 4. Chemical Sciences and Engineering Division, Argonne National Laboratory, 9700 South Cass Avenue, Lemont, \\ IL 60439, USA \\ 5. Nanoscience and Technology Division, Argonne National Laboratory, 9700 South Cass Avenue, Lemont, IL \\ 60439, USA \\ 6. X-ray Science Division, Advanced Photon Source, 9700 South Cass Avenue, Lemont, IL 60439, USA \\ 7. Department of Chemistry, Northwestern University, Evanston, Illinois 60208, USA
}




\section{Experimental Section:}

Characterizations. Powder X-ray diffraction (XRD) data were collected using a Rigaku Miniflex $\mathrm{X}$-ray diffractometer with $\mathrm{Cu} \mathrm{K} \alpha$ radiation, $\lambda=1.5418 \AA$. Lab single crystal XRD data were collected using a STOE diffractometer with $\mathrm{Cu} \mathrm{K} \alpha$ radiation. Synchrotron single crystal XRD data were collected at 15-IDD at the advanced photon source (APS). Microscopic images were examined on a Hitachi SU-70 SEM field emission scanning electron microscope (SEM), and their elemental compositions were determined by energy dispersive X-ray spectroscopy (EDS) using a BRUKER EDS detector.

\section{X-ray Absorption Near-edge Structure (XANES) and Extended X-ray Absorption Fine} Structure (EXAFS). The Ni K-edge was probed in fluorescence (Ni Ka emissions) yield detection mode, with samples at a grazing incidence with respect to beam path using a 12-element Canberra solid-state Ge detector at Sector 20-BM of the Advanced Photon Source (APS) at Argonne National Laboratory. The Demeter 0.9.25 XAS data processing software package ${ }^{1}$ was used for post-processing of the Ni K edge XAS spectral data with normalization, background subtraction, and generation of the $\chi(\mathrm{k})$ data performed in ATHENA. The $\chi(\mathrm{k})$ data (Extended X-ray Absorption Fine Structure, "EXAFS", region) was processed and modeled using FEFF/ARTEMIS ${ }^{2}$ with a CIF file $\left(\mathrm{Ni}_{2} \mathrm{~S} \mathrm{Cmcm}\right)$ used as the FEFF input file (cluster size of $5 \AA$ with $~ 38$ atoms and 50 pathways generated with $\mathrm{Ni}$ as the absorber atom and $\mathrm{Ni} / \mathrm{S}$ set as scatterers) was compiled using ATOMS. ${ }^{3}$ A $k$-weight of 2 was used for the backwards Fourier transform of the reciprocal-space EXAFS (Hanning window).

\section{X-ray photoelectron spectroscopy (XPS)}

XPS measurements were carried out on a Thermo Scientific K-Alpha+ spectrometer using a microfocused monochromatic $\mathrm{Al} \mathrm{K \alpha}(1487 \mathrm{eV}) \mathrm{x}$-ray source with a spot size of $400 \mu \mathrm{m}$ for the surface analysis. A dual-beam electron flood gun (ultra-low energy coaxial electron and Ar+ ion beam) was used for charge compensation during all surface analyses. The instrument uses a 128-channel $180^{\circ}$ double-focusing analyzer and energy ranges of $0-1350 \mathrm{eV}$ were swept for wide-scan surveys. High-resolution XPS measurements were performed for $\mathrm{C} 1$ s (captured in $\mathrm{K} 2 \mathrm{p}$ scan window), $\mathrm{Li}$ $1 \mathrm{~s}, \mathrm{O} 1 \mathrm{~s}, \mathrm{Ni} 2 \mathrm{p}$ and $\mathrm{S} 2 \mathrm{p}$, at the relevant binding energy range for these features. The spectra were processed using Thermo Scientific Advantage (v. 5.977, Build 06436) post-processing software. 
Charge-correction was performed by referencing to the adventitious $\mathrm{C} 1 \mathrm{~s}$ peak arising at $284.8 \mathrm{eV}$. Peak deconvolution of the HR-XPS spectra was performed using mixed Gaussian-Lorentzian ( 30\% L/G) line shapes and Smart background.

\section{Theoretical methods}

We adopted the density functional theory (DFT) calculation to compute the band structure and the Fermi surface of $\mathrm{KNi}_{4} \mathrm{~S}_{2}$ and $\mathrm{Ni}_{2} \mathrm{~S}$ using Vienna Ab-initio Simulation Package (VASP). ${ }^{4,5}$ The Perdew-Burke-Ernzerhof for solids (PBE-sol $)^{6}$ implementation was used as the exchangecorrelation functional within DFT. The gamma-centered Monkhorst-Pack $k$-point mesh of $8 \times 8 \times 2$ and the plane-wave energy cutoff of $400 \mathrm{eV}$ were used for both materials.

Synthesis: For a typical reaction, $\mathrm{Ni}(\mathrm{OH})_{2}$ and $\mathrm{S}$ were ground with a hydroxide flux consisting of a mixture of $\mathrm{LiOH}$ and $\mathrm{KOH}$. The molar ration of $\mathrm{Ni}(\mathrm{OH})_{2}: \mathrm{S}$ was kept constant at about 1:2.5 to ensure excess amount of $\mathrm{S}$ for the Ni source. Hence, there are only two synthetic variables for starting precursors: concentrations of $\mathrm{LiOH}$ and $\mathrm{S}$ in the initial mixture, defined as $[\mathrm{LiOH}]=$ $n(\mathrm{LiOH}) /[n(\mathrm{LiOH})+n(\mathrm{KOH})]$ and $[\mathrm{S}]=n(\mathrm{~S}) /[n(\mathrm{LiOH})+n(\mathrm{KOH})]$, respectively. Once all the starting materials were thoroughly mixed, they were loaded into a glassy carbon crucible and then placed in a quartz tube. The quartz tube was placed in a tube furnace horizontally with both ends connecting to O-ring sealed metal flanges that allowed an inert gas, such as $\mathrm{N}_{2}$ to pass through during the reaction. For reactions shown in Fig.1, the furnace was heated at a rate of $20{ }^{\circ} \mathrm{C} / \mathrm{min}$ to $450{ }^{\circ} \mathrm{C}$, and then kept at $450{ }^{\circ} \mathrm{C}$ for $20-30$ hours and then cooled to room temperature (RT) at a rate of $7-50{ }^{\circ} \mathrm{C}$ /hour. The fast heating rate was to ensure the molten hydroxide exhibits an intended flux ratio since at eutectic point of $220{ }^{\circ} \mathrm{C}$, the $[\mathrm{LiOH}]$ is about 0.3 . An alternative approach is to preheat the furnace to $450{ }^{\circ} \mathrm{C}$ and then place the quartz tube in place. Because the initial nucleation of ternary K-Ni-S is a fast step as demonstrated by in-situ diffraction shown in Fig. 2b, slow heating rate could kinetically stabilize products that are favored at low [LiOH]. This is indeed the case when the heating rate is below $5{ }^{\circ} \mathrm{C} / \mathrm{min}$. After the furnace was cooled to RT, the reaction vessel was immersed in a beaker filled with water and then ultrasonicated until all hydroxides were dissolved. The precipitates of ternary K-Ni-S were obtained by decantation of the solution and subsequent washing with ethanol and dried in air. All ternary products appeared to be stable in air.

For reactions at $450{ }^{\circ} \mathrm{C}$, we found when using pure $\mathrm{LiOH}$ or $\mathrm{KOH}$, the as-recovered products were binary $\mathrm{Ni}_{3} \mathrm{~S}_{2}$ and $\mathrm{Ni}$ metal, respectively. This indicates at high basicity, $\mathrm{Ni}^{2+}$ tends to oxidize 
$\mathrm{S}^{2-}$ to form Ni metal, which is the stable Ni form under this condition. In general, when $[\mathrm{LiOH}]<$ 0.3 or $[\mathrm{S}]<0.08$ only Ni metal was afforded. As shown in Fig.1, when $0.3<[\mathrm{LiOH}]<0.7$, higher $[\mathrm{LiOH}]$ and $[\mathrm{S}]$ favored the formation of $\mathrm{Ni}(\mathrm{II})$ ternaries in the form of $\mathrm{K}_{2} \mathrm{Ni}_{3} \mathrm{~S}_{4}$-related phases. For $[\mathrm{LiOH}]=0.70$ and $[\mathrm{S}]=0.126$, the phase was the known $\alpha-\mathrm{K}_{2} \mathrm{Ni}_{3} \mathrm{~S}_{4}$ compound $(F d d d$ ) with a very strong preferred orientation for the (004) reflection (Fig. S1b), which is reasonable considering its layered structure type. However, for $[\mathrm{LiOH}]=0.54$ and $[\mathrm{S}]=0.162$, a similar phase with (004) reflection shifting to slightly higher $d$-space (or lower angle) at about $0.1 \AA$ was observed. This difference is large enough to imply a structural change even though the sample still has a composition close to 234 (Fig. S2a and b). As a matter of fact, most $\mathrm{K}_{2} \mathrm{Ni}_{3} \mathrm{~S}_{4}$ samples recovered consisted of a mixture of these two phases and clearly showed overlap of different (004) reflections. When $\mathrm{NiO}$ was used as the $\mathrm{Ni}$ source instead of $\mathrm{Ni}(\mathrm{OH})_{2}$, the reaction became much slower due to lower solubility of $\mathrm{NiO}$ in molten hydroxides compared to $\mathrm{Ni}(\mathrm{OH})_{2}$. Hence, we obtained a mixture with three overlapping peaks around $13^{\circ}$ shown in Fig. S1a. The two peaks on the right clearly correspond to the phases shown in Fig. S1b and c. However, the third phase with even larger $d$-space was never observed for reaction at $450{ }^{\circ} \mathrm{C}$ using $\mathrm{Ni}(\mathrm{OH})_{2}$. We were able to isolate the pure form of this new phase with a composition of $\mathrm{K}_{4} \mathrm{Ni}_{9} \mathrm{~S}_{11}$ (Fig. S2c) by reactions at $350{ }^{\circ} \mathrm{C}$ using $\mathrm{Ni}(\mathrm{OH})_{2}$ and index it to a $P 2 / m$ space group with $a=7.16(1) \AA, b=13.98(2) \AA, c=$ 5.232(9) $\AA$ and $\beta=110.6(1)^{\circ}$ (Fig. S1d). Therefore, this phase is likely to be an intermediate phase converting to $\mathrm{K}_{2} \mathrm{Ni}_{3} \mathrm{~S}_{4}$, which was also seen for reactions at $350{ }^{\circ} \mathrm{C}$ but never isolated at $450{ }^{\circ} \mathrm{C}$ using $\mathrm{Ni}(\mathrm{OH})_{2}$. We attribute the new phase shown in Fig. $\mathbf{S 1 b}$ as a polytypic $\mathrm{K}_{2} \mathrm{Ni}_{3} \mathrm{~S}_{4}$ with the space group of $P_{6} / m m c$ and the $\mathrm{K}_{4} \mathrm{Ni}_{9} \mathrm{~S}_{11}$ phase as a variation of $\mathrm{K}_{2} \mathrm{Ni}_{3} \mathrm{~S}_{4}$. We will further explain their structures in the section for the polytypism in $\mathrm{K}_{2} \mathrm{Ni}_{3} \mathrm{~S}_{4}$. 


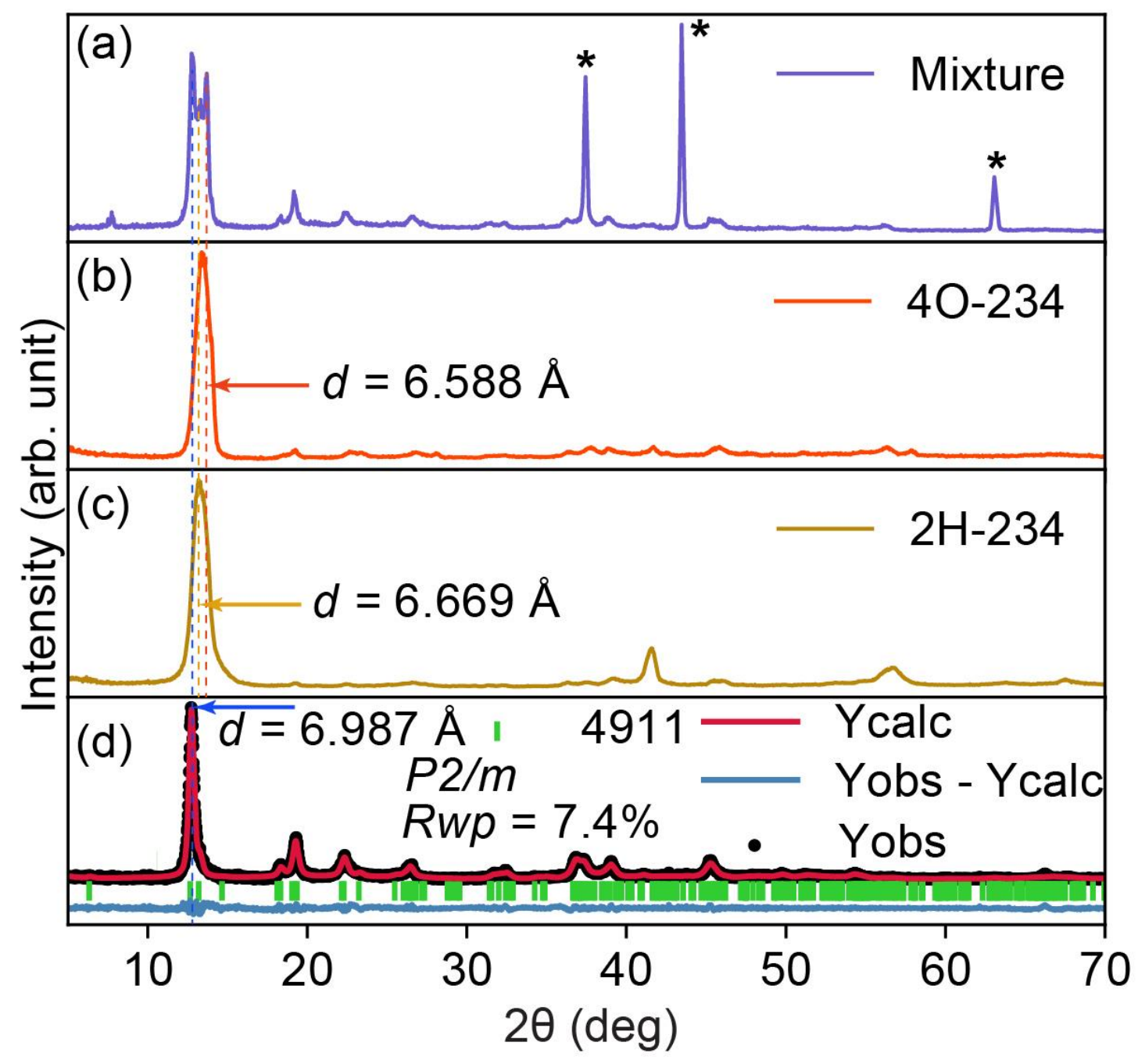

Figure S1. PXRD patterns of a) a mixture of $\mathrm{K}_{2} \mathrm{Ni}_{3} \mathrm{~S}_{4}$-related phases using $\mathrm{NiO}$ as the Ni source, b) $4 \mathrm{O}$ $\mathrm{K}_{2} \mathrm{Ni}_{3} \mathrm{~S}_{4}$ in the space group of $F d d d$, c) $2 \mathrm{H}-\mathrm{K}_{2} \mathrm{Ni}_{3} \mathrm{~S}_{4}$ in the space group of $P 6_{3} / m m c$, and d) a new phase $\mathrm{K}_{4} \mathrm{Ni}_{9} \mathrm{~S}_{11}$. The new phase shown in $\mathrm{d}$ ) is indexed to a $P 2 / m$ space group with $a=7.16(1) \AA, b=13.98(2)$ $\AA, c=5.232(9) \AA$ and $\beta=110.6(1)^{\circ}$. The lattice parameters were extracted using the Pawley routine in TOPAS $5 .^{7}$ The symbol "*" in a) indicates unreacted NiO. 

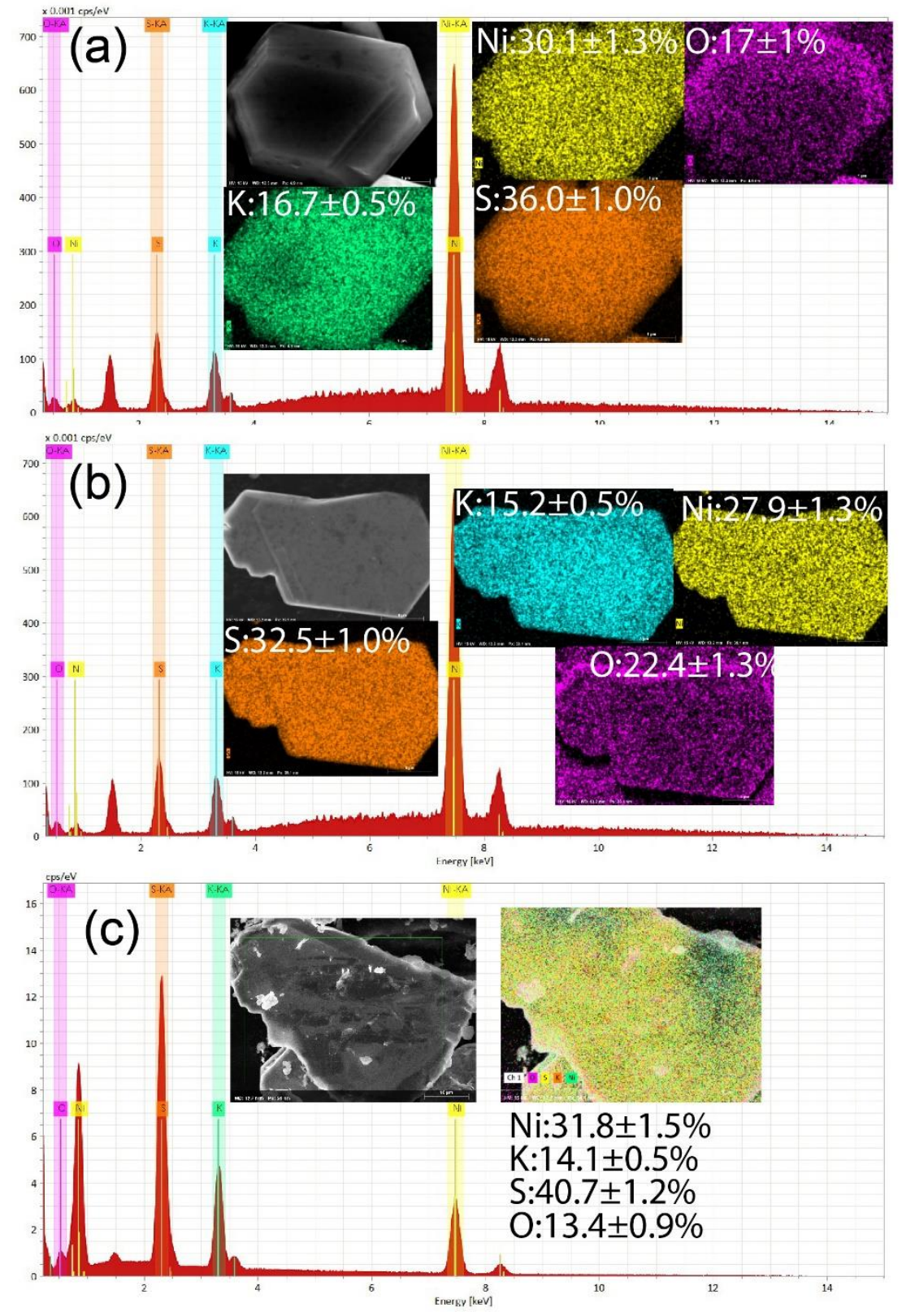

Figure S2. Elemental analysis for a) $4 \mathrm{O}-\mathrm{K}_{2} \mathrm{Ni}_{3} \mathrm{~S}_{4}$ shown in Fig. $\mathbf{S 1 b}$, b) $2 \mathrm{H}-\mathrm{K}_{2} \mathrm{Ni}_{3} \mathrm{~S}_{4}$ shown in Fig. S1c and c) the $\mathrm{K}_{4} \mathrm{Ni}_{9} \mathrm{~S}_{11}$ phase shown in Fig. S1d.

When $[\mathrm{S}]<0.15$, we started to see the formation of the $\mathrm{ThCr}_{2} \mathrm{Si}_{2}$-type $\mathrm{KNi}_{2} \mathrm{~S}_{2}$ (122). The phase boundary between 122 and 234 were determined by reactions with a mixture of both phases. Below the boundary shown in Fig. 1, only pure 122 phase was recovered (Fig. S3b, Table S2). Interestingly, when $[\mathrm{S}]$ was further decreased to the boundary close to the Ni metal dominate region in Fig. 1, a new phase started to emerge usually as a mixture with $\mathrm{KNi}_{2} \mathrm{~S}_{2}$ (Fig. S3a). Using single 
crystal diffraction, this new phase was identified as $\mathrm{KNi}_{4} \mathrm{~S}_{2}$ (Fig. S3c and Table S3). To obtain the pure and pristine form of $\mathrm{KNi}_{4} \mathrm{~S}_{2}$ without the presence of $\mathrm{KNi}_{2} \mathrm{~S}_{2}$, a heating rate below $5{ }^{\circ} \mathrm{C} / \mathrm{min}$ was applied. This can be attributed to the initial nucleation of 142 at lower temperature (300-400 ${ }^{\circ} \mathrm{C}$ ) with higher $[\mathrm{KOH}]$ since the melting point of $\mathrm{KOH}$ is lower than $\mathrm{LiOH}$. Once the phase is stabilized as 142, it is kinetically stable in solution even when the temperature is increased to 450 ${ }^{\circ} \mathrm{C}$. For a heating rate of $5{ }^{\circ} \mathrm{C} / \mathrm{min}$ we show the conditions for the 142 and 122 phase in Table S1. This shows a similar trend as the predominate diagram shown in Fig. 2a, higher [ $\mathrm{LiOH}]$ and $[\mathrm{S}]$ favor the formation of ternaries with higher Ni oxidation state. In addition, when increasing [ $\mathrm{LiOH}]$ or [S] from a pristine $\mathrm{KNi}_{4} \mathrm{~S}_{2}$, the afforded product could exhibit $\mathrm{K}$ vacancy to accommodate a higher Ni oxidation state (Fig. S3d and Table S4).

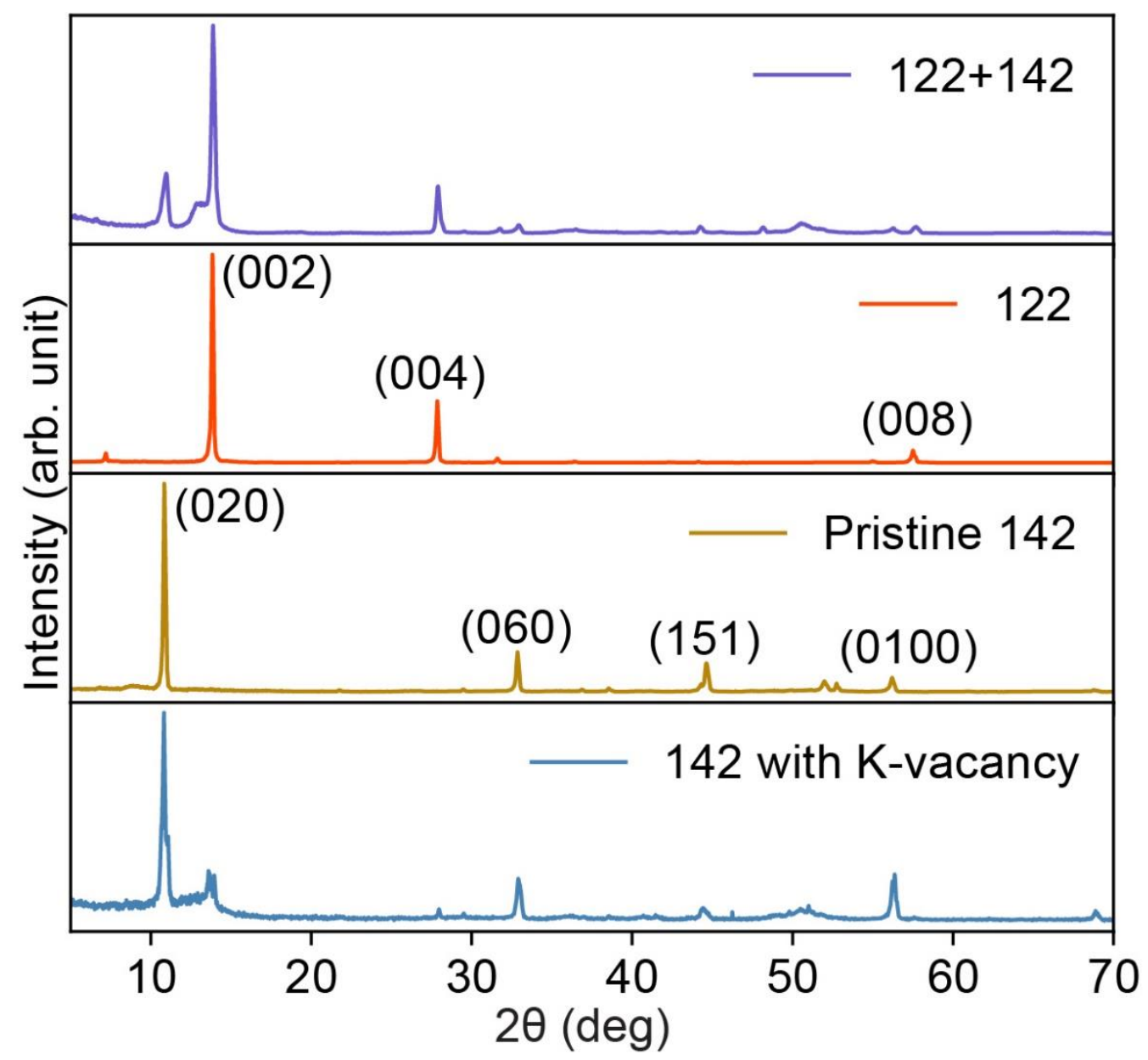

Figure S3. PXRD patterns of a) a mixture of $\mathrm{KNi}_{2} \mathrm{~S}_{2}$ and $\mathrm{KNi}_{4} \mathrm{~S}_{2}$, b) pure $\mathrm{KNi}_{2} \mathrm{~S}_{2}$, c) pure $\mathrm{KNi}_{2} \mathrm{~S}_{4}$, and d) $\mathrm{K}_{1-\mathrm{x}} \mathrm{Ni}_{2} \mathrm{~S}_{4}(x \approx 0.7)$. The $\mathrm{K}$ vacancy in $\mathrm{K}_{1-\mathrm{x}} \mathrm{Ni}_{2} \mathrm{~S}_{4}$ is a result of partial deintercalation due to higher $\mathrm{Ni}$ oxidation state favored by the flux. In addition, it forms $\mathrm{K}$ vacancy-order and a superstructure as shown in Table S3. 
Table S1. Results of the product as a function of synthetic variables ([LiOH] and $[\mathrm{S}])$ at a heating rate of 5 ${ }^{\circ} \mathrm{C} / \mathrm{min}$ to $450{ }^{\circ} \mathrm{C}$.

\begin{tabular}{ccc}
\hline$[\mathrm{LiOH}]$ & {$[\mathrm{S}]$} & Phase \\
\hline \hline 0.68 & 0.175 & 122 \\
0.73 & 0.180 & 122 \\
0.73 & 0.097 & 142 \\
0.66 & 0.093 & 142 \\
0.54 & 0.162 & 142 \\
\hline
\end{tabular}

Polytypism in $\mathbf{K}_{2} \mathbf{N i}_{3} \mathbf{S}_{4}$ : Polytypism is commonly seen in transition metal dichalcogenides with honeycomb lattices. ${ }^{8}$ Similarly for the 234-type structure, $\mathrm{NiS}_{4}$ square-planes edge-share to enclose empty hexagon cones. The stacking sequence for these hexagon cones gives the possibility of polytypism in the 234-type compounds. Although only one structure type of $\mathrm{K}_{2} \mathrm{Ni}_{3} \mathrm{~S}_{4}$ is reported, ${ }^{9}$ there are three different polytopes among all $A_{2} \mathrm{Ni}_{3} \mathrm{~S}_{4}(A=\mathrm{K}, \mathrm{Rb}$ and $\mathrm{Cs})$ as illustrated in Fig. S4. ${ }^{10}$ For the $F d d d \mathrm{~K}_{2} \mathrm{Ni}_{3} \mathrm{~S}_{4}$, the consequent translational vectors for each neighboring layers is $\boldsymbol{r}_{1}=(-1 / 4,1 / 4), \boldsymbol{r}_{2}=(-$ $1 / 4,-1 / 4), \boldsymbol{r}_{3}=(1 / 4,-1 / 4)$ and $\boldsymbol{r}_{4}=(1 / 4,1 / 4)$. Thus for each unit cell of $\mathrm{K}_{2} \mathrm{Ni}_{3} \mathrm{~S}_{4}$, there are 4 different layers as $\sum_{1}^{4} \boldsymbol{r}_{\boldsymbol{n}}=(0,0)$. The Fmmm type is reported for 234 compound with $A=\mathrm{Rb}$ and Cs, where $\boldsymbol{r}=(0,1 / 2)$ or $(1 / 2,0)$. Therefore, after the second translation operation, the projection of the $3^{\text {rd }}$ layer overlaps with that of the $1^{\text {st }}$ layer. Hence, there are two different layers in the Fmmm type. For the hexagonal $P 6_{3} / m m c$ type, it is only found in $\mathrm{Cs}_{2} \mathrm{Ni}_{3} \mathrm{~S}_{4}$, where $\boldsymbol{r}=(1 / 3,-1 / 3) .{ }^{10}$ Due to the symmetry of the hexagonal lattice, after the $2^{\text {nd }}$ operation, the $3^{\text {rd }}$ layer overlaps with the first layer. Hence, we name the $F d d d, F m m m$ and $P 6_{3} / m m c$ as the $4 \mathrm{O}-, 2 \mathrm{O}$ - and $2 \mathrm{H}-\mathrm{A}_{2} \mathrm{Ni}_{3} \mathrm{~S}_{4}$, respectively to denote its polytypism.

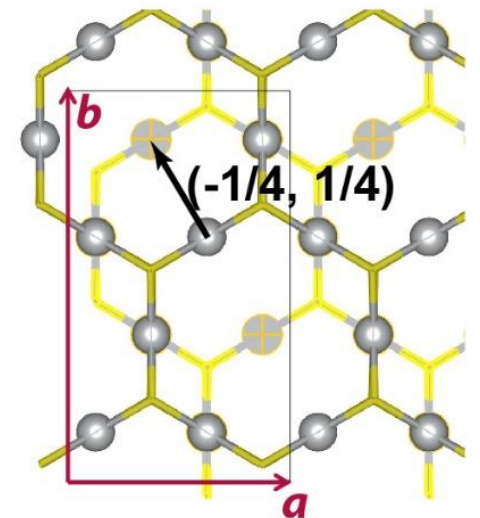

a) Fddd

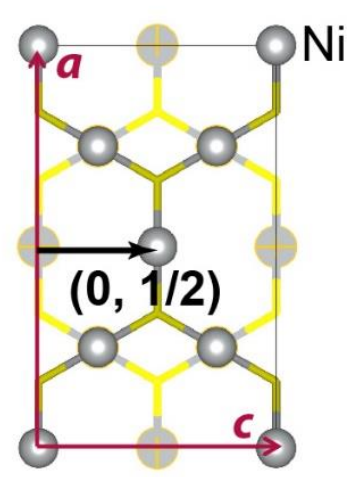

b) $F m m m$

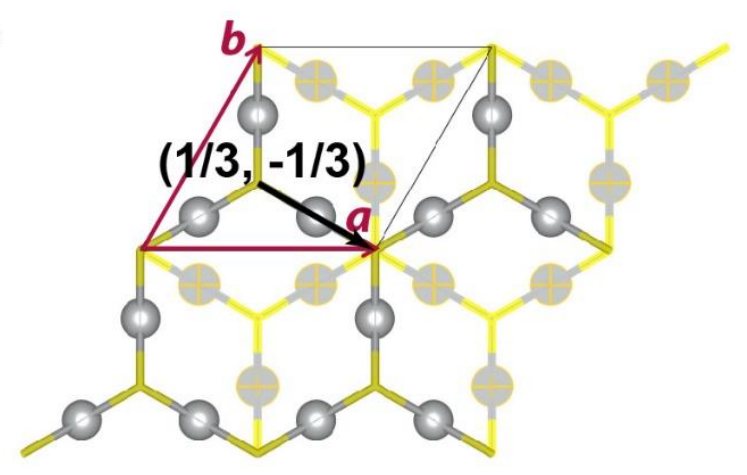

c) $P 6_{3} / m m c$

Figure S4. Illustration of neighboring Ni-S layers in different polytopes of $A_{2} \mathrm{Ni}_{3} \mathrm{~S}_{4}(A=\mathrm{K}, \mathrm{Rb}$ and $\mathrm{Cs})$ for space group of a) $F d d d$, b) $F m m m$ and c) $P 6_{3} / m m c$. The translational vector $\boldsymbol{r}$ for each neighboring layers are given as $(-1 / 4,1 / 4),(0,1 / 2)$ and $(1 / 3,-1 / 3)$ for a), b) and c), respectively. 
Although there are certain degrees of similarities between the polytopes of dichalcogenides and the 234 compounds, the biggest difference is that the large cavities enclosed by edge-sharing hexagons of $\mathrm{NiS}_{4}$ square-planes. The stacking sequence in dichalcogenides usually has little effect on the layer distance unless there are interstitial cations. ${ }^{8}$ However, for the 234-types, alkali cations could either partially fill the hexagon cavities or lie completely outside them depending on the stacking sequence, thus leading to different layered spacing based on its polytope. This is seen in the 2O- and 2H-types of $\mathrm{Cs}_{2} \mathrm{Ni}_{3} \mathrm{~S}_{4}$ where the layered spacing is about $0.3 \AA$ longer for the latter (Fig. S5). Now, we have explain the possible polytopes in 234-compounds, the new compound shown in Fig. S1c exhibits larger layered spacing $(\sim 0.1 \AA)$ and a composition close to $\mathrm{K}_{2} \mathrm{Ni}_{3} \mathrm{~S}_{4}$ (Fig. S2). Therefore, it is likely the hexagonal $2 \mathrm{H}$-type $\mathrm{K}_{2} \mathrm{Ni}_{3} \mathrm{~S}_{4}$. For the same formula with lower density compared to the 4O-type, this compound is likely a kinetic one stabilized by our low-temperature approach compared to the solid-state reaction at $8500^{\circ} \mathrm{C} .{ }^{9}$

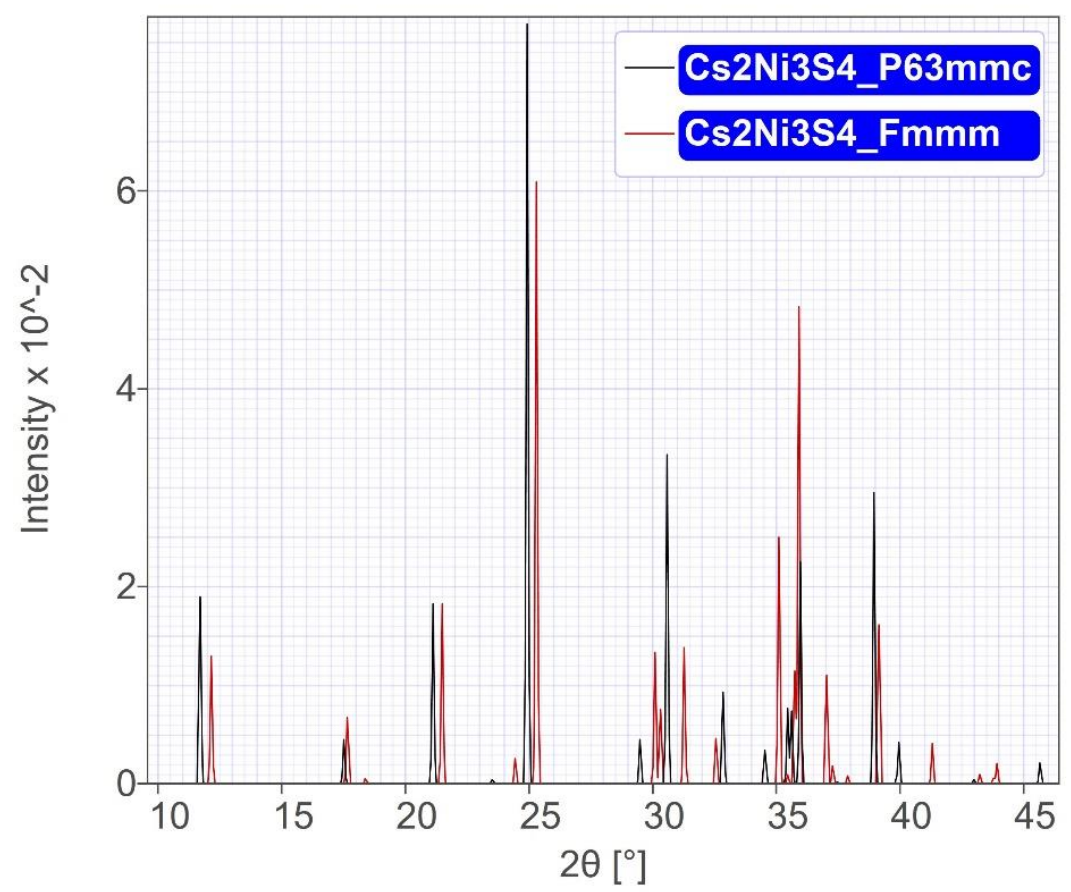

Figure S5. Comparison for X-ray diffraction pattern between Fmmm and $P 6_{3} / m m c$ types of $\mathrm{Cs}_{2} \mathrm{Ni}_{3} \mathrm{~S}_{4}$. The hexagonal type show larger layered spacing compared to the orthorhombic one, similar to the patterns shown in Fig S1. 


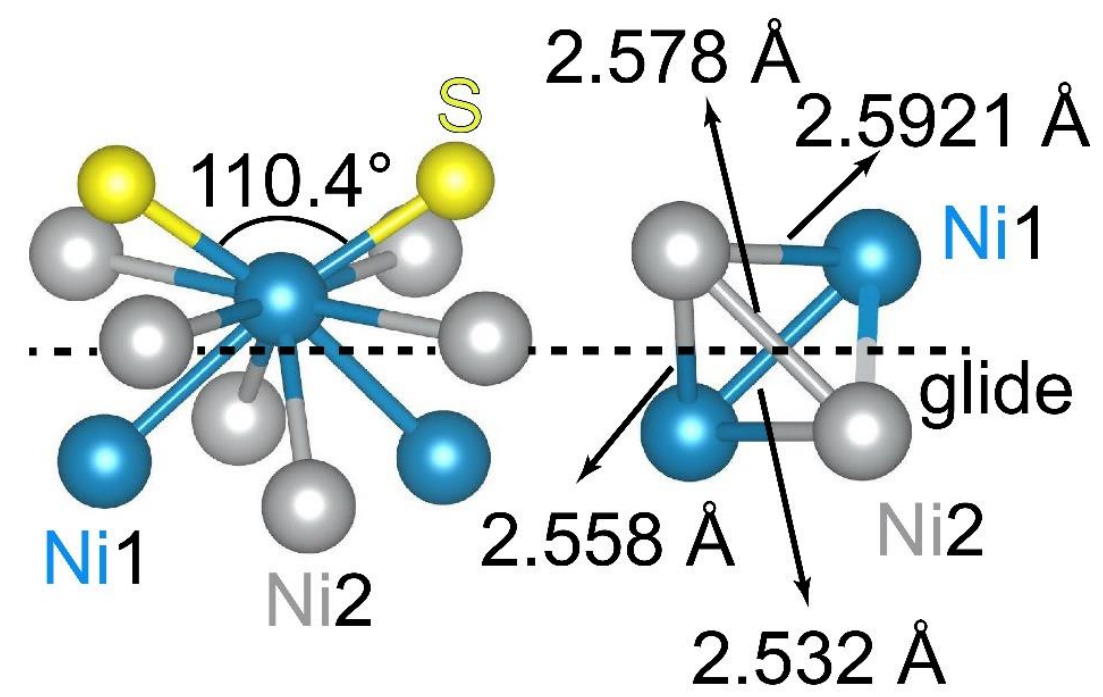

Figure S6. Nearest neighbors of Nil (left) and the tetrahedron formed by neighboring Ni atoms (right). $\mathrm{Ni1}, \mathrm{Ni} 2$ and $\mathrm{S}$ atoms are shown in blue, grey and yellow, respectively, and the glide plane between two neighboring Ni-layers are shown as dashed line.

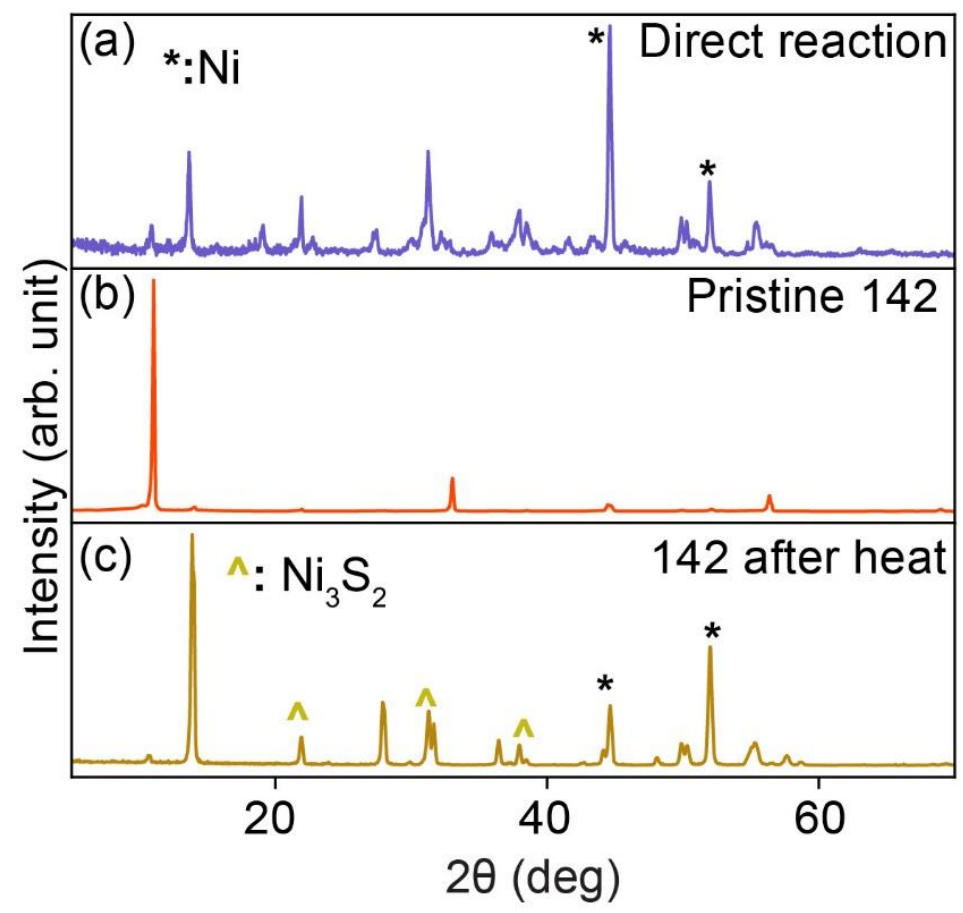

Figure S7. XRD patterns of a) direct reaction to $\mathrm{KNi}_{4} \mathrm{~S}_{2}$ with $\mathrm{Ni}$ and polysulfide flux $\left(16 \mathrm{Ni}+\mathrm{K}_{2} \mathrm{~S}_{3}+\mathrm{K}_{2} \mathrm{~S}_{5}\right)$ at $400{ }^{\circ} \mathrm{C}$, b) pristine $\mathrm{KNi}_{4} \mathrm{~S}_{2}$ and c) $\mathrm{KNi}_{4} \mathrm{~S}_{2}$ after heat treatment. The symbols * and ${ }^{\wedge}$ represent $\mathrm{Ni}$ and $\mathrm{Ni}_{3} \mathrm{~S}_{2}$, respectively. The major phases are $\alpha-\mathrm{K}_{2} \mathrm{Ni}_{3} \mathrm{~S}_{4}$ in a) and $\mathrm{KNi}_{2} \mathrm{~S}_{2}$ in c). 


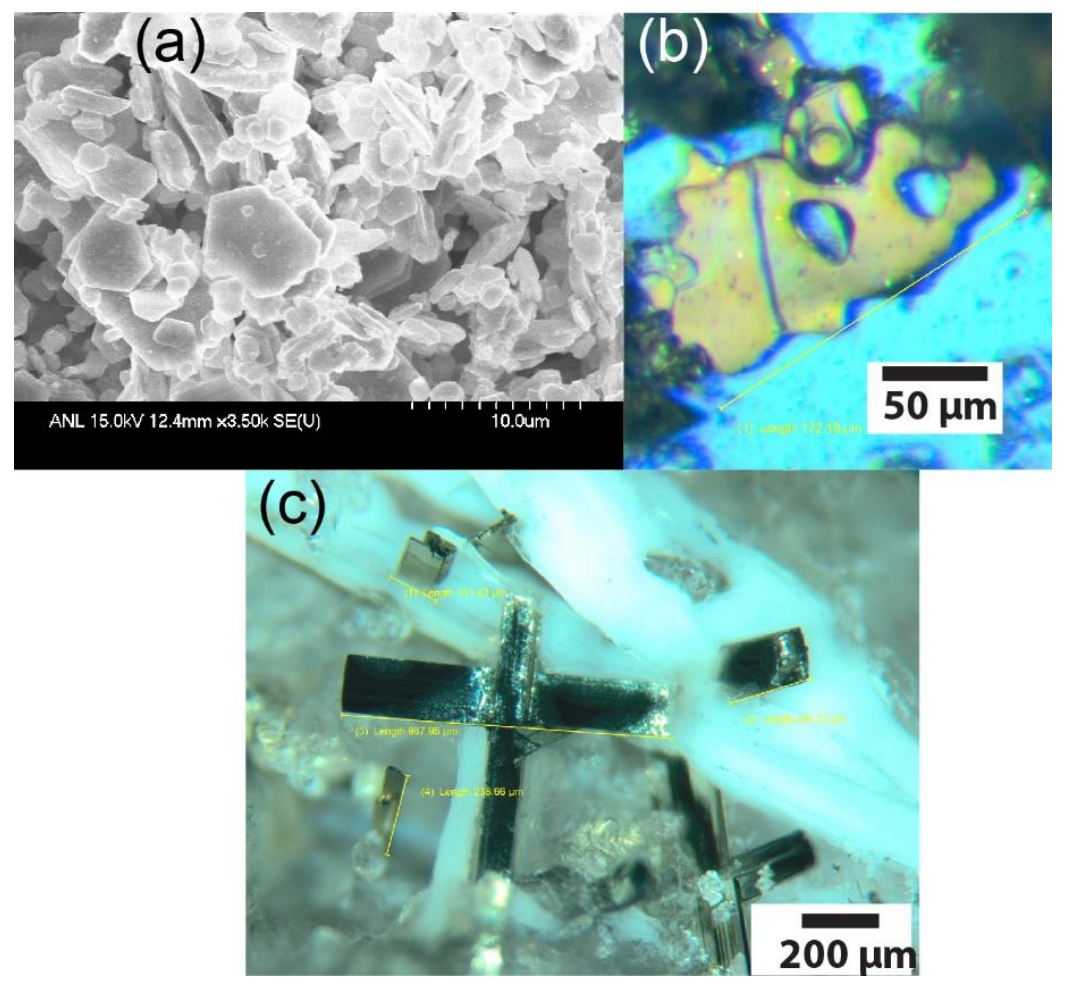

Figure S8. Images of crystals of a) $\mathrm{K}_{2} \mathrm{Ni}_{3} \mathrm{~S}_{4}$, b) $\mathrm{KNi}_{2} \mathrm{~S}_{2}$ and c) $\mathrm{KNi}_{4} \mathrm{~S}_{2}$ prepared with $[\mathrm{KOH}]=0.3,0.5$ and 0.7 , respectively. The image of a) is taken with an electron microscope and the images of b) and c) are taken with an optical microscope. 

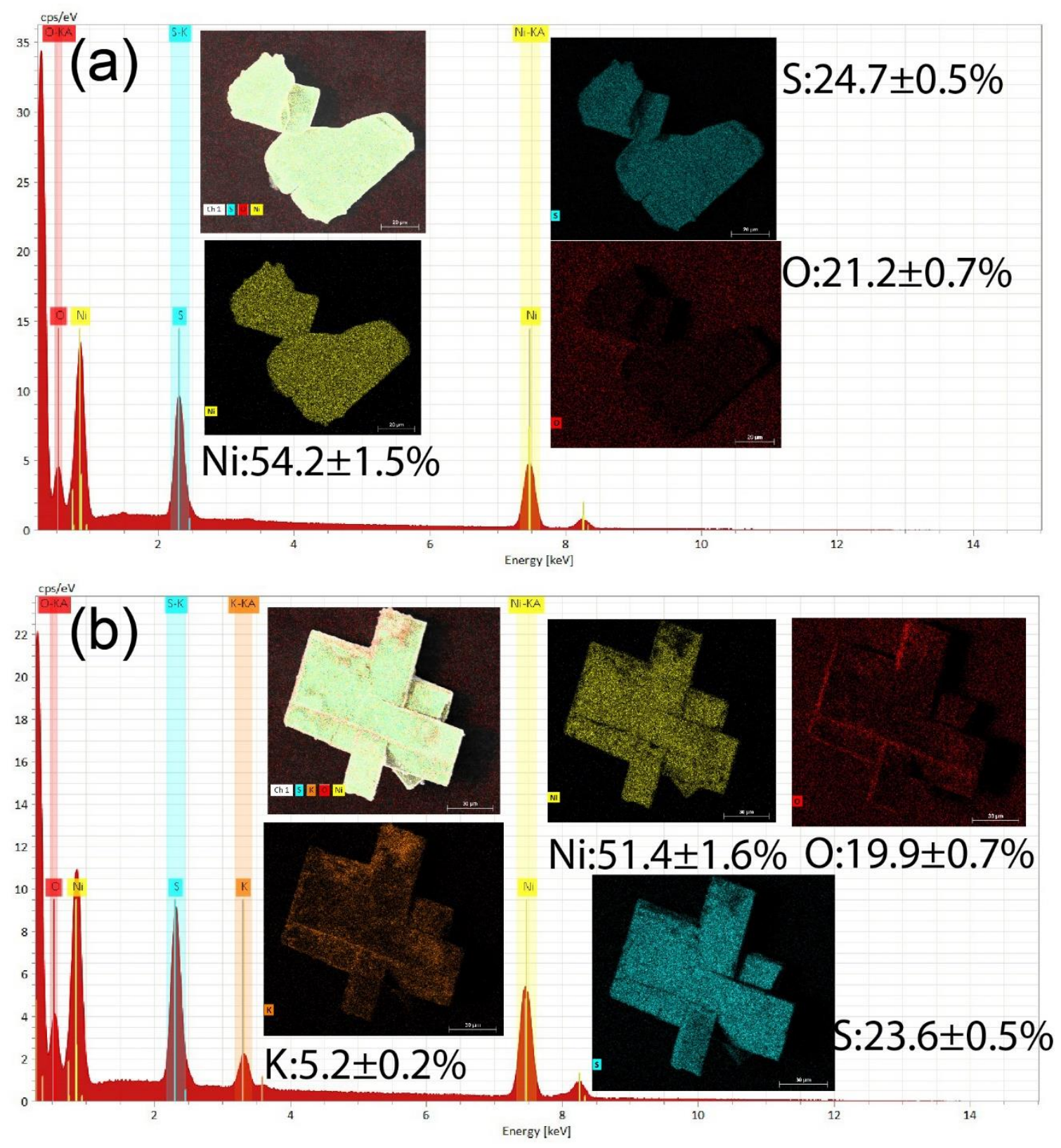

Figure S9. Elemental analysis for a) $\mathrm{Ni}_{2} \mathrm{~S}$ and b) $\mathrm{LiOH}$-intercalated $\mathrm{Ni}_{2} \mathrm{~S}$ shown in Fig. S2d and e), respectively. There is no $\mathrm{K}$ detected for $\mathrm{Ni}_{2} \mathrm{~S}$, whereas there is residual $\mathrm{K}$ in $\mathrm{LiOH}$-intercalated $\mathrm{Ni}_{2} \mathrm{~S}$ which is also supported by TEM analysis shown in Fig.3. 


\section{XPS Analysis}

The elemental oxidation states and composition of the various $\mathrm{Ni}_{2} \mathrm{~S}$-containing compounds were also assessed by high resolution X-ray photoelectron spectroscopy (XPS) analysis. Fig. S10 depicts the XPS data of the $\mathrm{Ni}_{2} \mathrm{~S}$ "control" sample used for this study. Prominent signals of interest consisted of Ni 2p, S 2p, O 1s, and C 1s (no K2p was detected, indicating successful removal). The Ni $2 p$ spectrum is highly sensitive to oxidation state changes and is typically comprised of peak fitting envelopes corresponding to the relevant $\mathrm{Ni}$ species $\left(\mathrm{Ni}^{0}, \mathrm{Ni} 2 \mathrm{~S}\right.$, and $\mathrm{NiO}$ in this case) with chemical shifts/photopeaks (binding energy, BE) that are related to the oxidation state of the Ni $2 p$ core level ( $2 p_{3 / 2}$ and $2 p_{1 / 2}$ spin-orbit split components at the lower and higher relative BE, respectively) and the satellite structure of each Ni species. ${ }^{11}$ The metallic Ni $2 p$ doublet (pink trace) arises at $852.6 \mathrm{eV}\left(2 \mathrm{p}_{3 / 2}\right.$ with $2 \mathrm{p}_{1 / 2}$ arising at $17.3 \mathrm{eV}$ higher $\mathrm{BE}$ of $\left.\sim 870 \mathrm{eV}\right)$. The dominant components for this sample are ascribed to the large $\mathrm{Ni}_{2} \mathrm{~S}$ doublet (blue trace) at $855.1 \mathrm{eV}$ and $\mathrm{Ni}^{2+} / \mathrm{Ni}^{3+}$ in oxide-bearing $\mathrm{Ni}$ (e.g. NiO) ${ }^{12}$ doublet that begins $\sim 857 \mathrm{eV}$. Line broadening is seen for the $\mathrm{NiO}$ (green trace) peak fitting envelope due to its overlap with the shake-up satellite peak

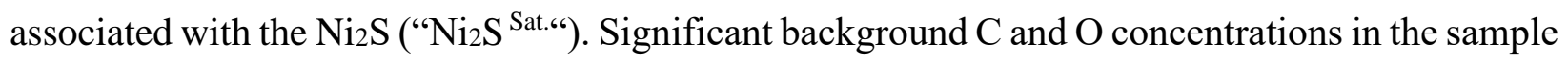
matrix made peak deconvolution of the $S 2 p$ region challenging, but it was nevertheless found that the $\mathrm{S} 2 \mathrm{p}$ signal is comprised mostly of oxysulfide-like Ni-O-S and C-S environments with a minor $\mathrm{Ni}_{2} \mathrm{~S}$ component (pink trace) centered $\sim 161 \mathrm{eV}$ which is associated with metal sulfides $\left(\mathrm{MS}^{2-}\right.$ ), with $\mathrm{Ni}$ as roughly $\mathrm{Ni}^{1+}$ in this case. Unlike the $\mathrm{Ni} 2 \mathrm{p}$ envelope $(\Delta=17 \mathrm{eV})$, the spin-orbit splitting of the $2 \mathrm{p}_{3 / 2} / 2 \mathrm{p}_{1 / 2}$ doublet is only $\Delta=1.16 \mathrm{eV}$, so partial overlap of metal oxide and sulfide peaks is inevitable. The $\mathrm{O} 1 \mathrm{~s}$ and $\mathrm{C}$ 1s XPS data shows mostly contributions from $\mathrm{H}_{2} \mathrm{O}_{\text {ads }} / \mathrm{C}-\mathrm{O} / \mathrm{C}=\mathrm{O} / \mathrm{C}-\mathrm{S}$ background contaminants with the minor NiO-based signal at $530.1 \mathrm{eV}^{12,13}$ and, interestingly, $\mathrm{SO}_{4-}$ based contaminants were absent. Overall the asymmetric line shape of the high-resolution Ni $2 p$ spectrum suggests a mixture of $\mathrm{Ni}$ oxidation states which is comprised mostly of $\mathrm{Ni}$-rich $\mathrm{Ni}_{2} \mathrm{~S}$ due to presence of the $\mathrm{Ni}^{1+}$ peak (major) and presence of metallic $\mathrm{Ni}$.

The high-resolution XPS spectra from $\mathrm{LiOH}-\mathrm{KNi}_{2} \mathrm{~S}$ is shown in Fig. S11 with Li 1s photopeaks associated with $\mathrm{Li}^{0}$ (which is necessarily $\mathrm{Li}$-rich $\mathrm{Li}$ oxide), $\mathrm{Li}_{2} \mathrm{O} / \mathrm{LiCO}_{3} / \mathrm{LiSO}_{4}$, and $\mathrm{LiOH}$ at $\mathrm{BE}$ values of 52.7, 54.1, and $55.6 \mathrm{eV}$, respectively. ${ }^{14}$ Due to a similar reactivity with ambient air as its alkali metal counterpart ( $\mathrm{Li}$ ), $\mathrm{K}$ cannot exist in its completely reduced form and therefore $\mathrm{SO}_{4}$ as well as OH-bearing $\mathrm{K}$ compounds are assigned on the basis of the $\mathrm{K} 2 \mathrm{p}$ high-resolution XPS spectrum. In addition to the $\mathrm{K} 2 \mathrm{p}$ doublet at $294.4 \mathrm{eV}$, there is partial overlap with the $\mathrm{C} 1 \mathrm{~s}$ region 
on the lower BE side $(<294 \mathrm{eV})$ and the loss peak associated with oxidized $\mathrm{K}$ at $300.7 \mathrm{eV}$. Due to the various oxide and sulfide-bearing $\mathrm{Li}$ and $\mathrm{K}$ species in the sample, absolute peak assignments in the narrow $\mathrm{O} 1 \mathrm{~s}$ region is not possible. However, the peak envelope centered at $530.7 \mathrm{eV}$ (green trace), $532.2 \mathrm{eV}$ (red trace), and 534.2 (blue trace) are attributed to bulk oxide $\left(\mathrm{O}^{2-}\right), \mathrm{OH}^{-1} / \mathrm{SO}_{4}{ }^{2-}$ and adsorbed $\mathrm{H}_{2} \mathrm{O}$ contributions associated with $\mathrm{Li} / \mathrm{K} / \mathrm{Ni}$, respectively. ${ }^{11-14}$ Compared to $\mathrm{Ni}_{2} \mathrm{~S}$, significant line broadening is observed for all $\mathrm{Ni} 2 \mathrm{p}$ sub-peaks with the $\mathrm{Ni} 2 \mathrm{p}$ onset beginning $\sim 852 \mathrm{eV}$ with minor $\mathrm{Ni}^{0}$ found at 853.5 and major $\mathrm{Ni}_{2} \mathrm{~S}$ peak arising at $856.4 \mathrm{eV}$. Due to the presence of many oxygen and sulfur-bearing $\mathrm{Ni}$ insulator species (indicated in Fig. S11), there is a slight charging effect we attribute to chemical shift of the more conductive $\mathrm{Ni}^{0}$ and $\mathrm{Ni}_{2} \mathrm{~S}$ subpeaks appearing at $0.9-1 \mathrm{eV}$ higher $\mathrm{BE}$ values relative to the $\mathrm{Ni}_{2} \mathrm{~S}$ sample. Due to the large energy separation of $\mathrm{S}^{2+}$ and $\mathrm{S}^{2-}$ based BE values, the $\mathrm{S} 2 \mathrm{p}$ high-resolution XPS spectrum reveals two distinct photopeak doublets corresponding to $\mathrm{Ni}_{2} \mathrm{~S}\left(\mathrm{~S} \mathrm{2} \mathrm{p}_{3 / 2}\right.$ of $160.3 \mathrm{eV}$ ) and the $\mathrm{Li} / \mathrm{K} / \mathrm{Ni}$-based $\mathrm{SO}_{4}$ compounds ( $\mathrm{S} 2 \mathrm{p}_{3 / 2}=168.1 \mathrm{eV}$ ).

Two other compounds, namely $\mathrm{KNi}_{4} \mathrm{~S}_{2}$ (Fig. S12) and $\mathrm{KNi}_{2} \mathrm{~S}_{2}$ (Fig. S13), where $\mathrm{Ni}$ exists in $\mathrm{Ni}^{+0.75}$ and $\mathrm{Ni}^{+1.5}$ oxidation states, respectively, were also analyzed by XPS. In the former case, the $\mathrm{Ni} 2 \mathrm{p}$ core level reveals photopeaks associated with primarily $\mathrm{Ni}^{0}$ (dominant blue sub-peak arising at $852.6 \mathrm{eV}$ in Fig. S12) along with a $\mathrm{Ni}_{2} \mathrm{~S}$ (monomeric units that make up $\mathrm{Ni}_{4} \mathrm{~S}_{2}$ ) with an associated $\mathrm{Ni} 2 \mathrm{p}_{3 / 2}$ sub-peak arising (green trace) at $855.2 \mathrm{eV}$. The Ni $2 \mathrm{p}$ peak envelope for this sample is largely asymmetric, indicating that the $\mathrm{Ni}$ character is mostly metallic as expected for the effectively Ni-rich $\mathrm{KNi}_{4} \mathrm{~S}_{2}$ compound. ${ }^{11,12}$ The $\mathrm{K} 2 \mathrm{p}$ and $\mathrm{O}$ 1s regions are comprised of the $\mathrm{CO}_{3}$ and $\mathrm{OH}$-bearing $\mathrm{K}$ species as well as minor contribution from the bulk $\mathrm{NiO}$ inclusion (O1s subpeak at $529.8 \mathrm{eV}^{12}$ ). In addition to the expected $\mathrm{Ni}_{2} \mathrm{~S}$ contribution at $\sim 162 \mathrm{eV}$ in the $\mathrm{S} 2 \mathrm{p}$ XPS spectrum, there is a minor $\mathrm{S} 2 \mathrm{p}$ doublet (red trace) at $\sim 165 \mathrm{eV}$ that is attributed to partially oxidized $\mathrm{Ni}_{4} \mathrm{~S}_{2}$ to form Ni-S=O wherein the $\mathrm{S}=\mathrm{O}$ is likely a $\mathrm{SO}_{3}$-bearing species (e.g. $\mathrm{Ni}_{2}\left(\mathrm{SO}_{3}\right)_{2}$ ) since a $\mathrm{SO}_{4}$-based doublets appear at $\mathrm{BE}>168 \mathrm{eV}$ as observed in $\mathrm{LiOH}-\mathrm{KNi}_{2} \mathrm{~S}$ and metal sulfates in general. ${ }^{11}$ 

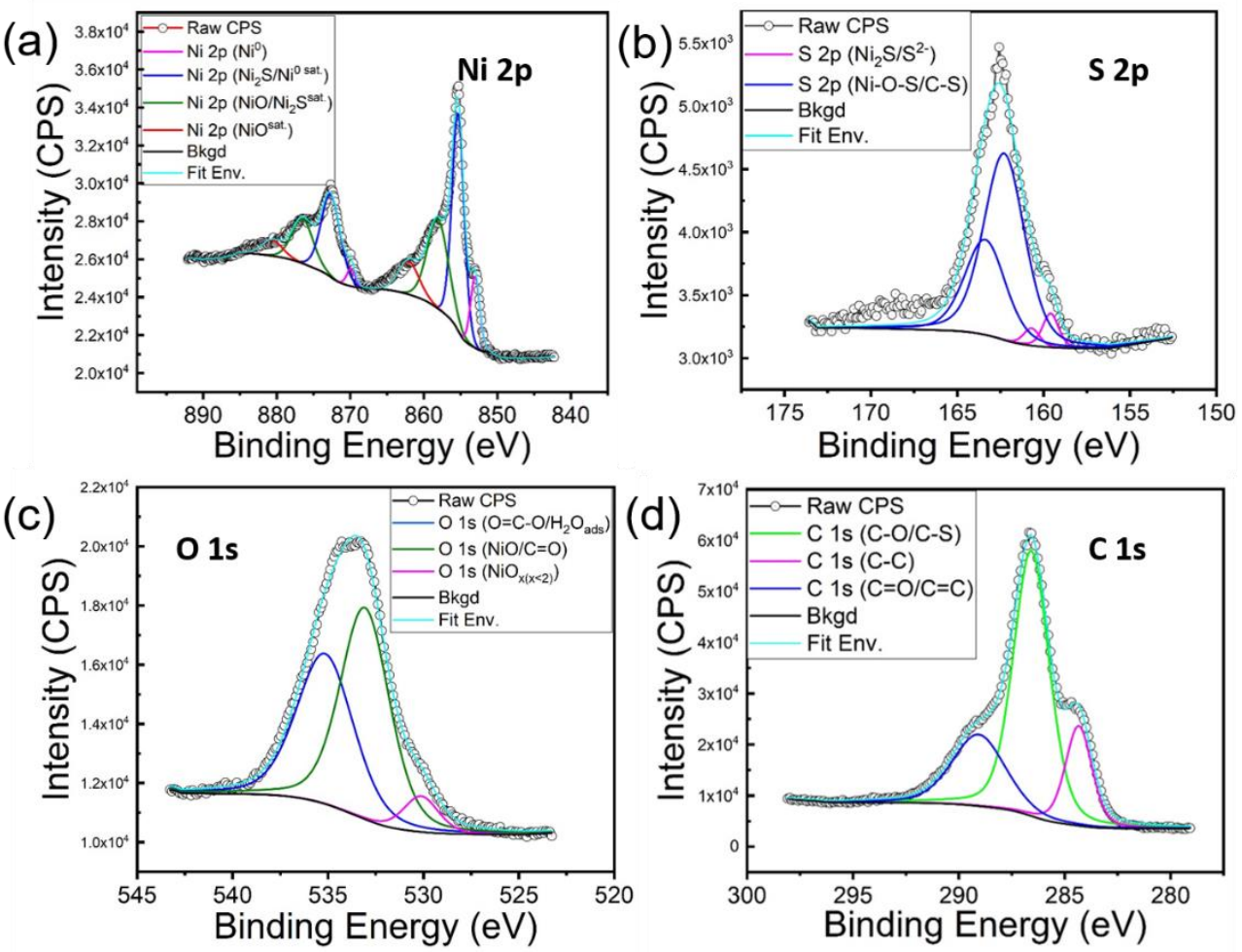

Figure S10. XPS results for $\mathrm{Ni}_{2} \mathrm{~S}$ showing a) Ni-2p, b) $\mathrm{S}-2 \mathrm{p}$, c) O-1s and d) C-1s. 

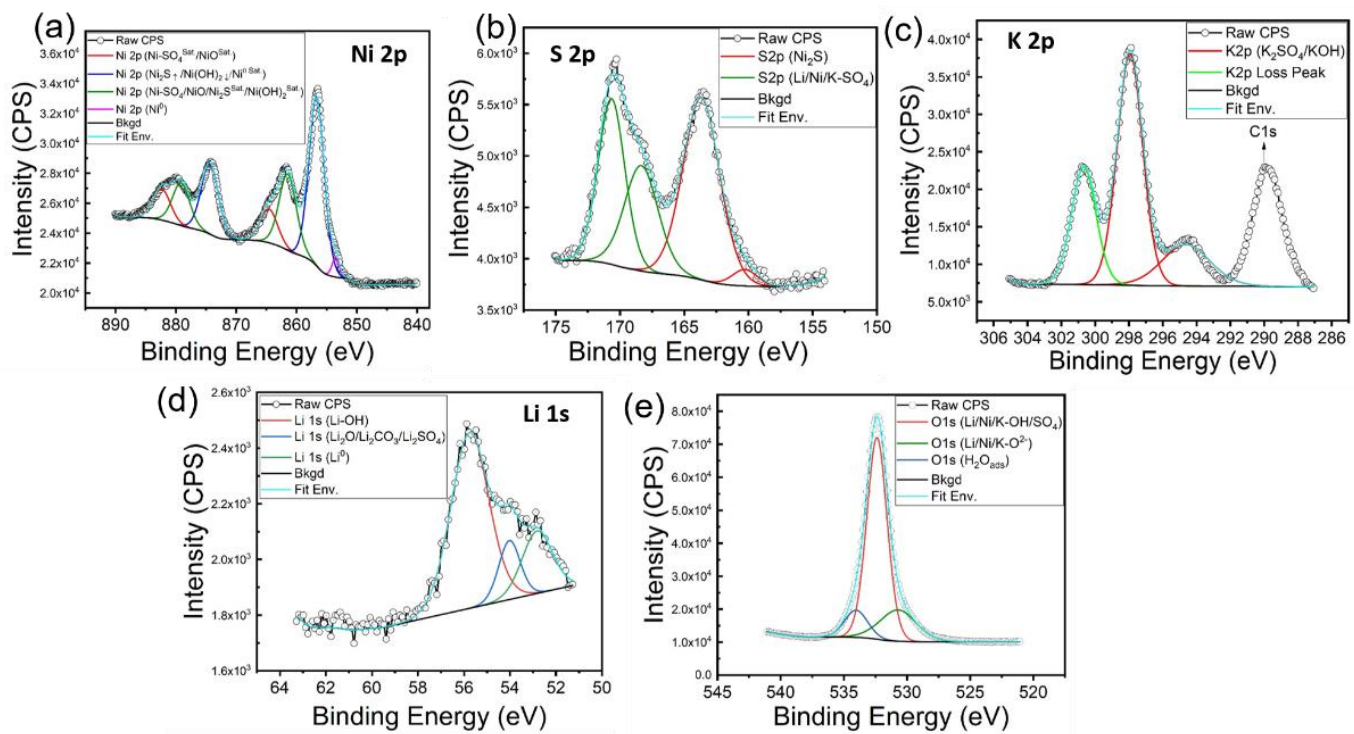

Figure S11. XPS results for $\mathrm{LiOH}-\mathrm{Ni}_{2} \mathrm{~S}$ showing a) Ni-2p, b) S-2p, c) K-2p, d) Li-1s and e) O-1s.
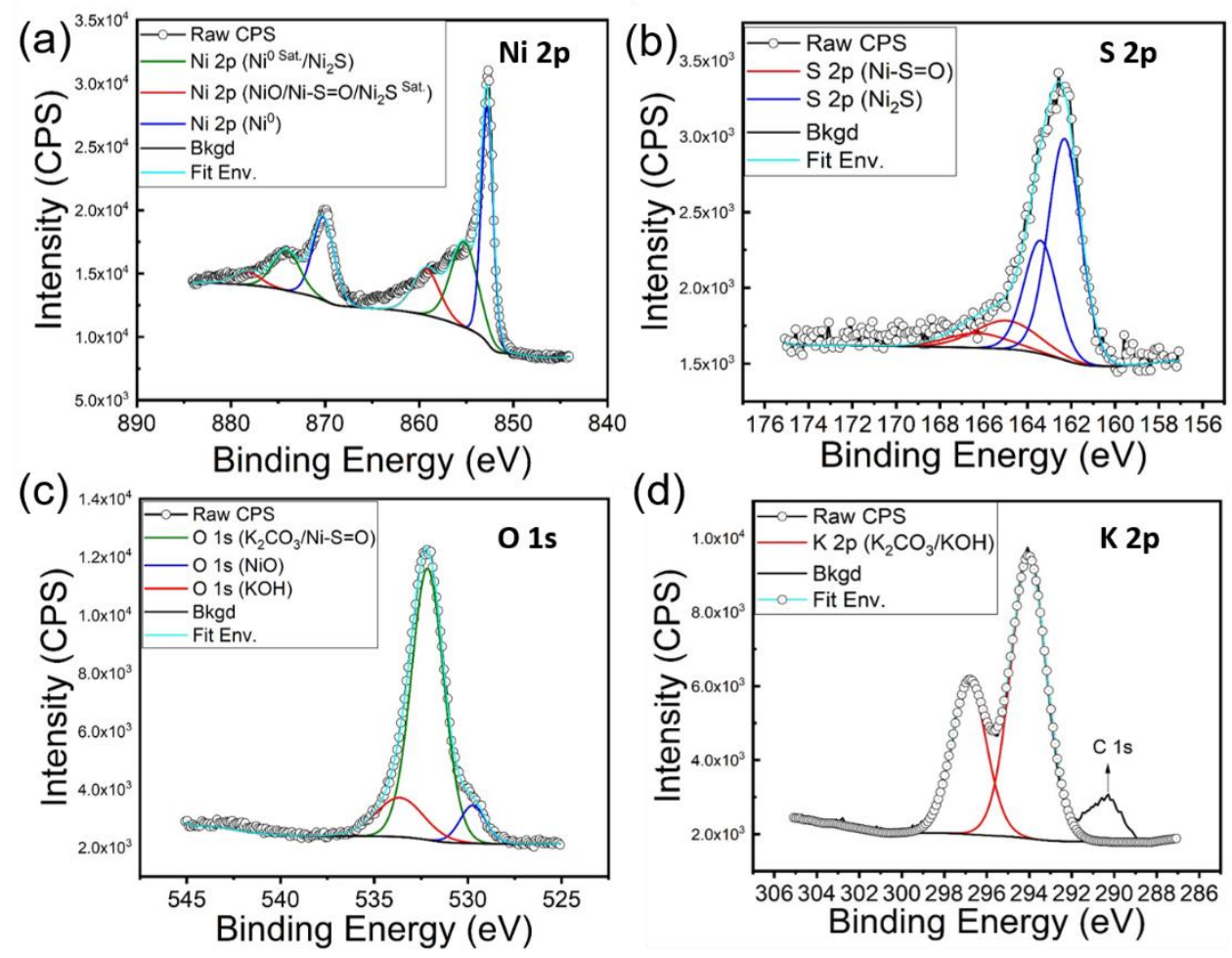

Figure S12. XPS results for $\mathrm{KNi}_{4} \mathrm{~S}_{2}$ showing a) Ni-2p, b) S-2p, c) O-1s and d) K-2p. 

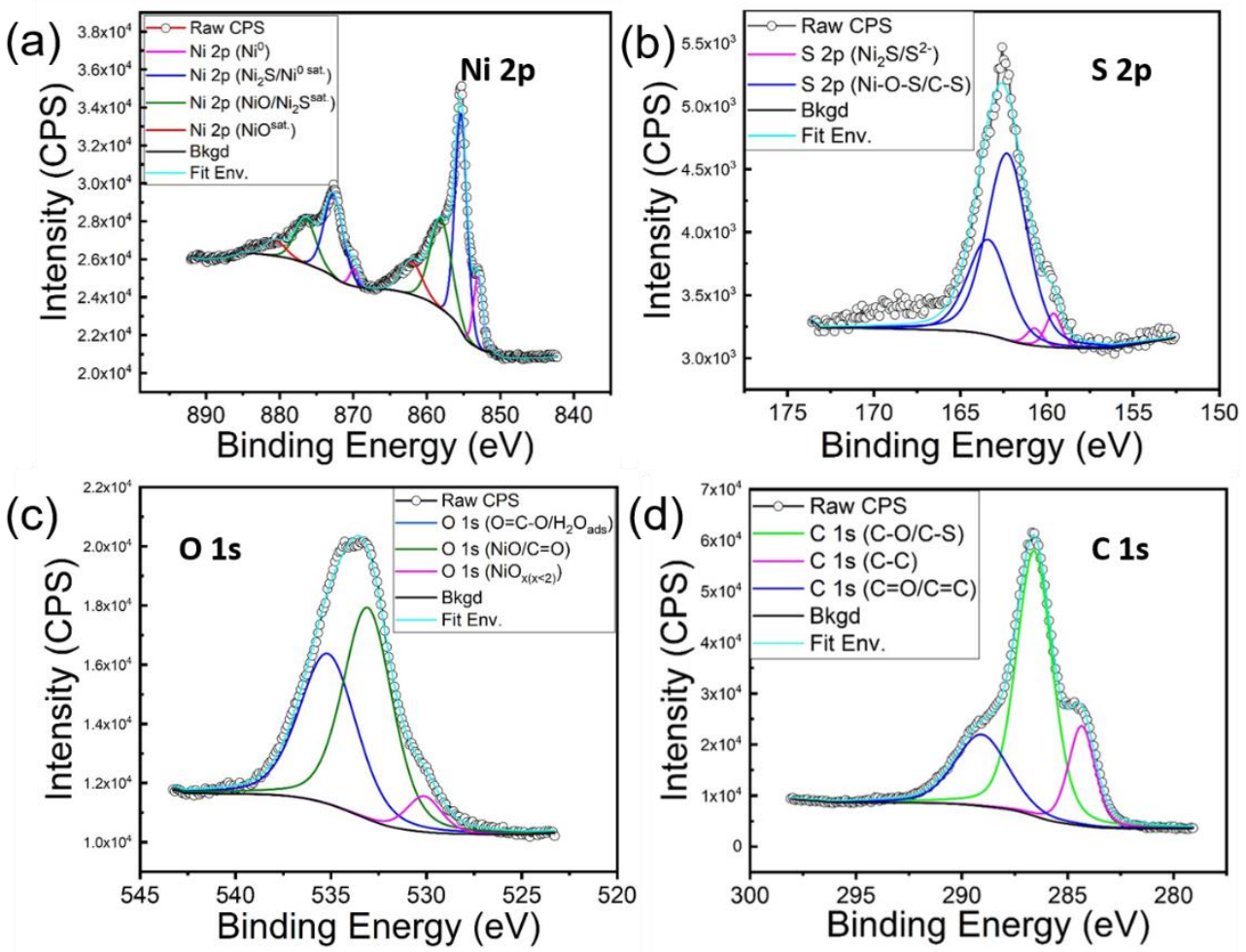

Figure S13. XPS results for $\mathrm{Ni}_{2} \mathrm{~S}$ showing a) Ni-2p, b) $\mathrm{S}-2 \mathrm{p}$, c) O-1s and d) C-1s. 
Table S2. Single crystal diffraction data of $\mathrm{KNi}_{4} \mathrm{~S}_{2}$

\begin{tabular}{|c|c|}
\hline Empirical formula & $\mathrm{KNi}_{4} \mathrm{~S}_{2}$ \\
\hline Formula weight & 338.06 \\
\hline Temperature/K & 293(2) \\
\hline Crystal system & orthorhombic \\
\hline Space group & Cmmm \\
\hline $\mathrm{a} / \AA$ & $3.6617(7)$ \\
\hline $\mathrm{b} / \AA$ & $16.381(3)$ \\
\hline $\mathrm{c} / \AA$ & $3.6694(7)$ \\
\hline$\alpha /{ }^{\circ}$ & 90 \\
\hline$\beta /{ }^{\circ}$ & 90 \\
\hline$\gamma /{ }^{\circ}$ & 90 \\
\hline Volume $/ \AA^{3}$ & $220.10(7)$ \\
\hline $\mathrm{Z}$ & 2 \\
\hline$\rho_{\text {calc }} \mathrm{g} / \mathrm{cm}^{3}$ & 5.101 \\
\hline$\mu / \mathrm{mm}^{-1}$ & 18.532 \\
\hline $\mathrm{F}(000)$ & 326.0 \\
\hline Radiation & $\operatorname{MoK} \alpha(\lambda=0.71073)$ \\
\hline \multicolumn{2}{|c|}{$2 \Theta$ range for data collection $/{ }^{\circ} 11.414$ to 58.264} \\
\hline Index ranges & $0 \leq \mathrm{h} \leq 5,0 \leq \mathrm{k} \leq 22,0 \leq 1 \leq 5$ \\
\hline Reflections collected & 182 \\
\hline Independent reflections & $182\left[\mathrm{R}_{\text {int }}=0.1264, \mathrm{R}_{\text {sigma }}=0.0381\right]$ \\
\hline Data/restraints/parameters & $182 / 0 / 16$ \\
\hline Goodness-of-fit on $\mathrm{F}^{2}$ & 0.994 \\
\hline Final $\mathrm{R}$ indexes $[\mathrm{I}>=2 \sigma(\mathrm{I})]$ & $\mathrm{R}_{1}=0.0591, \mathrm{wR}_{2}=0.1446$ \\
\hline Final $\mathrm{R}$ indexes [all data] & $\mathrm{R}_{1}=0.0779, \mathrm{w} \mathrm{R}_{2}=0.1486$ \\
\hline Largest diff. peak/hole / e $\AA$ & $3.96 /-1.66$ \\
\hline
\end{tabular}


Table S2 extended. Fractional Atomic Coordinates $\left(\times 10^{4}\right)$ and Equivalent Isotropic Displacement Parameters $\left(\AA^{2} \times 10^{3}\right)$. $U_{\text {eq }}$ is defined as $1 / 3$ of of the trace of the orthogonalized $\mathrm{U}_{\mathrm{IJ}}$ tensor for $\mathrm{KNi}_{4} \mathrm{~S}_{2}$.

$\begin{array}{lccccc}\text { Atom } & \boldsymbol{x} & \boldsymbol{y} & \boldsymbol{z} & \mathbf{U}(\mathbf{e q}) & \text { Wyckoff } \\ \mathrm{Ni01} & 10000 & 6966.1(16) & 5000 & 22.6(7) & 4 \mathrm{j} \\ \mathrm{Ni02} & 5000 & 6946.2(16) & 0 & 22.6(7) & 4 \mathrm{i} \\ \mathrm{K} 003 & 0 & 5000 & 0 & 28.8(15) & 2 \mathrm{~b} \\ \text { S004 } & 5000 & 6189(3) & 5000 & 21.8(11) & 4 \mathrm{j}\end{array}$

Table S2 extended. Anisotropic Displacement Parameters $\left(\AA^{2} \times 10^{3}\right)$ for $\mathrm{KNi}_{4} \mathrm{~S}_{2}$. The Anisotropic displacement factor exponent takes the form: $-2 \pi^{2}\left[h^{2} a^{* 2} U_{11}+2 h k a * b * U_{12}+\ldots\right]$.

$\begin{array}{lcccccc}\text { Atom } & \mathbf{U}_{\mathbf{1 1}} & \mathbf{U}_{\mathbf{2 2}} & \mathbf{U}_{\mathbf{3 3}} & \mathbf{U}_{\mathbf{2 3}} & \mathbf{U}_{\mathbf{1 3}} & \mathbf{U}_{\mathbf{1 2}} \\ \mathrm{Ni01} & 11.5(10) & 37.8(14) & 18.5(12) & 0 & 0 & 0 \\ \text { Ni02 } & 16.6(11) & 36.3(14) & 14.8(12) & 0 & 0 & 0 \\ \text { K003 } & 18(3) & 44(4) & 25(3) & 0 & 0 & 0 \\ \text { S004 } & 13.6(19) & 36(2) & 16(2) & 0 & 0 & 0\end{array}$


Table S3. Single crystal diffraction data of $\mathrm{KNi}_{2} \mathrm{~S}_{2}$

\begin{tabular}{|c|c|}
\hline Empirical formula & $\mathrm{KNi}_{2} \mathrm{~S}_{2}$ \\
\hline Formula weight & 220.64 \\
\hline Temperature/K & 293(2) \\
\hline Crystal system & tetragonal \\
\hline Space group & $I 4 / \mathrm{mmm}$ \\
\hline $\mathrm{a} / \AA$ & $3.7873(5)$ \\
\hline $\mathrm{b} / \AA$ & $3.7873(5)$ \\
\hline $\mathrm{c} / \AA$ & $12.827(3)$ \\
\hline$\alpha /^{\circ}$ & 90 \\
\hline$\beta /{ }^{\circ}$ & 90 \\
\hline$\gamma /{ }^{\circ}$ & 90 \\
\hline Volume $/ \AA^{3}$ & $183.99(6)$ \\
\hline $\mathrm{Z}$ & 2 \\
\hline$\rho_{\text {calc }} \mathrm{g} / \mathrm{cm}^{3}$ & 3.983 \\
\hline$\mu / \mathrm{mm}^{-1}$ & 12.234 \\
\hline $\mathrm{F}(000)$ & 214.0 \\
\hline Radiation & $\operatorname{MoK} \alpha(\lambda=0.71073)$ \\
\hline \multicolumn{2}{|c|}{$2 \Theta$ range for data collection $/{ }^{\circ} 11.23$ to 58.026} \\
\hline Index ranges & $-3 \leq \mathrm{h} \leq 3,0 \leq \mathrm{k} \leq 5,0 \leq 1 \leq 17$ \\
\hline Reflections collected & 156 \\
\hline Independent reflections & $98\left[\mathrm{R}_{\text {int }}=0.0684, \mathrm{R}_{\text {sigma }}=0.0674\right]$ \\
\hline Data/restraints/parameters & $98 / 0 / 8$ \\
\hline Goodness-of-fit on $\mathrm{F}^{2}$ & 0.875 \\
\hline Final $R$ indexes $[I>=2 \sigma(I)]$ & $\mathrm{R}_{1}=0.0436, \mathrm{wR}_{2}=0.1069$ \\
\hline Final $\mathrm{R}$ indexes [all data] & $\mathrm{R}_{1}=0.0527, \mathrm{wR}_{2}=0.1079$ \\
\hline Largest diff. peak/hole / e & $3.12 /-1.11$ \\
\hline
\end{tabular}


Table S3 Extended. Fractional Atomic Coordinates $\left(\times 10^{4}\right)$ and Equivalent Isotropic Displacement Parameters $\left(\AA^{2} \times 10^{3}\right)$. $U_{\text {eq }}$ is defined as $1 / 3$ of of the trace of the orthogonalized $\mathrm{U}_{\mathrm{IJ}}$ tensor for $\mathrm{KNi}_{2} \mathrm{~S}_{2}$.

$\begin{array}{lccccc}\text { Atom } & \boldsymbol{x} & \boldsymbol{y} & \boldsymbol{z} & \mathbf{U}(\mathbf{e q}) & \text { Wyckoff } \\ \mathrm{Ni} 01 & 10000 & 5000 & 7500 & 25.9(7) & 4 \mathrm{~d} \\ \mathrm{~K} 002 & 0 & 0 & 5000 & 29.8(12) & 2 \mathrm{~b} \\ \mathrm{~S} 003 & 5000 & 5000 & 6502(3) & 22.9(9) & 4 \mathrm{e}\end{array}$

Table S3 Extended Anisotropic Displacement Parameters $\left(\AA^{2} \times 10^{3}\right)$ for $\mathrm{KNi}_{2} \mathrm{~S}_{2}$. The Anisotropic displacement factor exponent takes the form: $-2 \pi^{2}\left[h^{2} a^{* 2} U_{11}+2 h k a * b * U_{12}+\ldots\right]$.

$\begin{array}{lcccccc}\text { Atom } & \mathbf{U}_{11} & \mathbf{U}_{22} & \mathbf{U}_{\mathbf{3 3}} & \mathbf{U}_{\mathbf{2 3}} & \mathbf{U}_{\mathbf{1 3}} & \mathbf{U}_{\mathbf{1 2}} \\ \text { Ni01 } & 16.5(7) & 16.5(7) & 44.7(13) & 0 & 0 & 0 \\ \text { K002 } & 25.1(17) & 25.1(17) & 39(3) & 0 & 0 & 0 \\ \text { S003 } & 15.9(12) & 15.9(12) & 37(2) & 0 & 0 & 0\end{array}$


Table S4. Single crystal diffraction data of $\mathrm{K}_{1-\mathrm{x}} \mathrm{Ni}_{4} \mathrm{~S}_{2}$. It forms a superlattice compared to the pristine structure in Table S3.

\begin{tabular}{|c|c|}
\hline Empirical formula & $\mathrm{K}_{1.35} \mathrm{Ni}_{6} \mathrm{~S}_{3}$ \\
\hline Formula weight & 501.03 \\
\hline Temperature/K & 293(2) \\
\hline Crystal system & monoclinic \\
\hline Space group & $P 2{ }_{1} / m$ \\
\hline $\mathrm{a} / \AA$ & $8.3840(17)$ \\
\hline $\mathrm{b} / \AA$ & $7.3350(15)$ \\
\hline$c / \AA$ & $10.994(2)$ \\
\hline$\alpha /{ }^{\circ}$ & 90 \\
\hline$\beta /{ }^{\circ}$ & $102.58(3)$ \\
\hline$\gamma /{ }^{\circ}$ & 90 \\
\hline Volume $/ \AA^{3}$ & $659.9(2)$ \\
\hline $\mathrm{Z}$ & 4 \\
\hline$\rho_{\text {calc }} \mathrm{g} / \mathrm{cm}^{3}$ & 5.043 \\
\hline$\mu / \mathrm{mm}^{-1}$ & 18.446 \\
\hline $\mathrm{F}(000)$ & 966.0 \\
\hline Radiation & $\operatorname{MoK} \alpha(\lambda=0.71073)$ \\
\hline \multicolumn{2}{|c|}{$2 \Theta$ range for data collection $/{ }^{\circ} 6.728$ to 58.452} \\
\hline Index ranges & $-11 \leq \mathrm{h} \leq 11,0 \leq \mathrm{k} \leq 10,0 \leq 1 \leq 15$ \\
\hline Reflections collected & 1900 \\
\hline Independent reflections & $1900\left[\mathrm{R}_{\mathrm{int}}=0.2995, \mathrm{R}_{\mathrm{sigma}}=0.1147\right]$ \\
\hline Data/restraints/parameters & $1900 / 0 / 116$ \\
\hline Goodness-of-fit on $\mathrm{F}^{2}$ & 0.937 \\
\hline Final $R$ indexes $[\mathrm{I}>=2 \sigma(\mathrm{I})]$ & $\mathrm{R}_{1}=0.1082, \mathrm{wR}_{2}=0.2878$ \\
\hline Final $\mathrm{R}$ indexes [all data] & $\mathrm{R}_{1}=0.2800, \mathrm{wR}_{2}=0.3003$ \\
\hline Largest diff. peak/hole / e $\AA^{-}$ & $4.77 /-2.94$ \\
\hline
\end{tabular}


Table S4 extended. Fractional Atomic Coordinates $\left(\times 10^{4}\right)$ and Equivalent Isotropic Displacement Parameters $\left(\AA^{2} \times 10^{3}\right)$ for $\mathrm{K}_{1-\mathrm{x}} \mathrm{Ni}_{4} \mathrm{~S}_{2}$. $\mathrm{U}_{\text {eq }}$ is defined as $1 / 3$ of of the trace of the orthogonalized $\mathrm{U}_{\mathrm{IJ}}$ tensor.

$\begin{array}{lccccc}\text { Atom } & \boldsymbol{x} & \boldsymbol{y} & \boldsymbol{z} & \mathbf{U}(\mathbf{e q}) & \begin{array}{c}\text { Wyckoff } \\ \text { Ni01 }\end{array} \\ \text { 8963(19) } & -2500 & 9006(9) & 30(3) & 2 \mathrm{e} \\ \text { Ni02 } & 8901(9) & 4996(14) & 7318(7) & 18.9(14) & 4 \mathrm{f} \\ \text { Ni03 } & 8912(13) & -2500 & 12324(10) & 15(2) & 2 \mathrm{e} \\ \text { Ni04 } & 8922(11) & 2500 & 8986(10) & 15(2) & 2 \mathrm{e} \\ \text { Ni05 } & 8905(10) & -1(12) & 10650(6) & 21.3(16) & 4 \mathrm{f} \\ \text { Ni06 } & 8910(14) & 2500 & 2305(11) & 17(2) & 2 \mathrm{e} \\ \text { Ni07 } & 8937(15) & 7500 & 5659(11) & 19(2) & 2 \mathrm{e} \\ \text { Ni08 } & 8896(8) & 4998(14) & 3983(6) & 16.4(14) & 4 \mathrm{f} \\ \text { Ni09 } & 8933(14) & 2500 & 5644(11) & 17(2) & 2 \mathrm{e} \\ \text { S00A } & 7370(30) & 2500 & 10389(17) & 10(4) & 2 \mathrm{e} \\ \text { K00B } & 5000 & 5000 & 5000 & 8(4) & 2 \mathrm{~d} \\ \text { K00C } & 4980(20) & 5000(30) & 8339(15) & 30(2) & 4 \mathrm{f} \\ \text { S00D } & 7390(30) & -2500 & 10430(30) & 28(5) & 2 \mathrm{e} \\ \text { S00E } & 7370(20) & 7500 & 3734(17) & 14(4) & 2 \mathrm{e} \\ \text { S00F } & 7360(40) & 2500 & 7050(30) & 58(9) & 2 \mathrm{e} \\ \text { S00G } & 7370(30) & 2500 & 3720(20) & 21(5) & 2 \mathrm{e} \\ \text { S00H } & 7370(30) & 7500 & 7053(19) & 21(4) & 2 \mathrm{e}\end{array}$

Table S4 extended. Anisotropic Displacement Parameters $\left(\AA^{2} \times 10^{3}\right)$ for $\mathrm{K}_{1-\mathrm{x}} \mathrm{Ni}_{4} \mathrm{~S}_{2}$. The Anisotropic displacement factor exponent takes the form: -

$2 \pi^{2}\left[h^{2} a^{* 2} U_{11}+2 h k a * b * U_{12}+\ldots.\right]$.

$\begin{array}{lcccccc}\text { Atom } & \mathbf{U}_{\mathbf{1 1}} & \mathbf{U}_{\mathbf{2 2}} & \mathbf{U}_{\mathbf{3 3}} & \mathbf{U}_{\mathbf{2 3}} & \mathbf{U}_{\mathbf{1 3}} & \mathbf{U}_{\mathbf{1 2}} \\ \mathrm{Ni01} & 94(10) & 1(5) & -3(4) & 0 & 10(5) & 0 \\ \mathrm{Ni02} & 31(3) & 16(3) & 10(3) & 1(3) & 6(3) & -1(4) \\ \mathrm{Ni03} & 21(4) & 14(5) & 10(5) & 0 & 5(4) & 0 \\ \mathrm{Ni04} & 8(4) & 22(6) & 14(5) & 0 & 3(3) & 0 \\ \mathrm{Ni05} & 53(4) & 1(2) & 8(3) & 0(3) & 2(3) & -1(4) \\ \mathrm{Ni06} & 28(5) & 13(5) & 9(5) & 0 & 4(4) & 0 \\ \mathrm{Ni07} & 39(6) & 11(5) & 5(5) & 0 & 4(5) & 0 \\ \text { Ni08 } & 27(3) & 9(3) & 15(4) & 0(3) & 7(3) & 1(3) \\ \text { Ni09 } & 30(5) & 13(5) & 9(5) & 0 & 4(4) & 0 \\ \text { S00A } & 37(9) & -7(7) & 3(8) & 0 & 10(7) & 0 \\ \text { K00B } & 11(7) & 3(7) & 11(10) & -1(9) & 4(6) & 2(9) \\ \text { K00C } & 60(6) & 16(4) & 15(4) & 0(6) & 9(4) & 3(8) \\ \text { S00D } & 49(12) & -2(8) & 35(14) & 0 & 7(11) & 0 \\ \text { S00E } & 26(9) & 9(9) & 3(8) & 0 & -2(7) & 0 \\ \text { S00F } & 64(17) & 90(30) & 24(14) & 0 & 20(13) & 0 \\ \text { S00G } & 36(11) & 15(11) & 12(10) & 0 & 9(9) & 0 \\ \text { S00H } & 29(10) & 23(11) & 5(9) & 0 & -6(8) & 0\end{array}$



Atom
Occupancy
K00B
$0.68(4)$

Table S5. Atomic coordinates for $\mathrm{KNi}_{4} \mathrm{~S}_{2}$ relaxed after density functional theory (DFT) calculation. The unit cell is $a=3.6995334 \AA, b=16.1797538 \AA$ and $c=3.6770486 \AA, \alpha=\beta=\gamma=90^{\circ}$. The coordinates of each atom is $\boldsymbol{u} a+\boldsymbol{v} b+\boldsymbol{w} c$.

\begin{tabular}{c|ccc}
\hline & $\boldsymbol{u}$ & $\boldsymbol{v}$ & $\boldsymbol{w}$ \\
\hline \hline $\mathrm{Ni} 1$ & 0.00000000 & 0.69705589 & 0.50000000 \\
$\mathrm{Ni} 2$ & 0.00000000 & 0.30294411 & 0.50000000 \\
$\mathrm{Ni3}$ & 0.50000000 & 0.19705589 & 0.50000000 \\
$\mathrm{Ni4}$ & 0.50000000 & 0.80294411 & 0.50000000 \\
$\mathrm{Ni5}$ & 0.50000000 & 0.69624095 & 0.00000000 \\
$\mathrm{Ni6}$ & 0.50000000 & 0.30375905 & 0.00000000 \\
$\mathrm{Ni}$ & 0.00000000 & 0.19624095 & 0.00000000 \\
$\mathrm{Ni} 8$ & 0.00000000 & 0.80375905 & 0.00000000 \\
$\mathrm{~K} 1$ & 0.00000000 & 0.50000000 & 0.00000000 \\
$\mathrm{~K} 2$ & 0.50000000 & 0.00000000 & 0.00000000 \\
S1 & 0.50000000 & 0.62582719 & 0.50000000 \\
S2 & 0.50000000 & 0.37417281 & 0.50000000 \\
S3 & 0.00000000 & 0.12582719 & 0.50000000 \\
S4 & 0.00000000 & 0.87417281 & 0.50000000 \\
\hline
\end{tabular}


Table S6. Atomic coordinates for $\mathrm{Ni}_{2} \mathrm{~S}$ relaxed after density functional theory (DFT) calculation. The unit cell is $a=3.5815447 \AA, b=13.8960128 \AA$ and $c=3.5042243 \AA, \alpha=\beta=\gamma=90^{\circ}$. The coordinates of each atom is $\boldsymbol{u} a+\boldsymbol{v} b+\boldsymbol{w} c$.

\begin{tabular}{c|ccc}
\hline & $\boldsymbol{u}$ & $\boldsymbol{v}$ & $\boldsymbol{w}$ \\
\hline \hline Ni1 & 0.00000000 & 0.68444614 & 0.50000000 \\
Ni2 & 0.50000000 & 0.31555386 & 0.00000000 \\
Ni3 & 0.00000000 & 0.18444614 & 0.00000000 \\
Ni4 & 0.50000000 & 0.81555386 & 0.50000000 \\
Ni5 & 0.50000000 & 0.68607644 & 0.00000000 \\
Ni6 & 0.00000000 & 0.31392356 & 0.50000000 \\
Ni7 & 0.50000000 & 0.18607644 & 0.50000000 \\
Ni8 & 0.00000000 & 0.81392356 & 0.00000000 \\
S1 & 0.50000000 & 0.59699271 & 0.50000000 \\
S2 & 0.00000000 & 0.40300729 & 0.00000000 \\
S3 & 0.50000000 & 0.09699271 & 0.00000000 \\
S4 & 0.00000000 & 0.90300729 & 0.50000000 \\
\hline
\end{tabular}

\section{References:}

1. Ravel, B.; Newville, M. ATHENA, ARTEMIS, HEPHAESTUS: data analysis for X-ray absorption spectroscopy using IFEFFIT. Journal of synchrotron radiation 2005, 12, 537.

2. Rehr, J. J.; Kas, J. J.; Vila, F. D.; Prange, M. P.; Jorissen, K. Parameter-free calculations of X-ray spectra with FEFF9. Physical Chemistry Chemical Physics 2010, 12, 5503.

3. Ravel, B. ATOMS: crystallography for the X-ray absorption spectroscopist. Journal of synchrotron radiation 2001, 8,314 .

4. Kresse, G.; Furthmüller, J. Efficient iterative schemes for ab initio total-energy calculations using a plane-wave basis set. Physical Review B 1996, 54, 11169.

5. Kresse, G.; Joubert, D. From ultrasoft pseudopotentials to the projector augmented-wave method. Physical Review B 1999, 59, 1758.

6. Perdew, J. P.; Ruzsinszky, A.; Csonka, G. I.; Vydrov, O. A.; Scuseria, G. E.; Constantin, L. A.; Zhou, X.; Burke, K. Restoring the Density-Gradient Expansion for Exchange in Solids and Surfaces. Physical Review Letters 2008, 100, 136406.

7. Coelho, A. A. TOPAS and TOPAS-Academic: an optimization program integrating computer algebra and crystallographic objects written in C++. Journal of Applied Crystallography 2018, 51, 210.

8. Rao, C. N. R.; Pisharody, K. P. R. Transition metal sulfides. Progress in Solid State Chemistry 1976, 10, 207.

9. Bronger, W.; Rennau, R.; Schmitz, D. Schichtstrukturen ternärer Chalkogenide $\mathrm{A}_{2} \mathrm{M}_{3} \mathrm{X}_{4}(\mathrm{~A} \triangleq \mathrm{K}, \mathrm{Rb}, \mathrm{Cs}$; $\mathrm{M} \triangleq \mathrm{Ni}, \mathrm{Pd}, \mathrm{Pt} ; \mathrm{X} \triangleq \mathrm{S}, \mathrm{Se})$. Zeitschrift für anorganische und allgemeine Chemie 1991, 597, 27.

10. Bronger, W.; Rennau, R.; Schmitz, D. Die Kristallstrukturen von Cs2Ni3S4. Zeitschrift für Kristallographie-Crystalline Materials 1988, 183, 201.

11. Grosvenor, A. P.; Biesinger, M. C.; Smart, R. S. C.; McIntyre, N. S. New interpretations of XPS spectra of nickel metal and oxides. Surface Science 2006, 600, 1771.

12. Nesbitt, H.; Legrand, D.; Bancroft, G. Interpretation of Ni2p XPS spectra of Ni conductors and Ni insulators. Physics and Chemistry of Minerals 2000, 27, 357. 
13. Fingerle, M.; Tengeler, S.; Calvet, W.; Mayer, T.; Jaegermann, W. Water interaction with sputterdeposited nickel oxide on n-Si photoanode: cryo photoelectron spectroscopy on adsorbed water in the frozen electrolyte approach. Journal of The Electrochemical Society 2018, 165, H3148.

14. Wood, K. N.; Teeter, G. XPS on Li-battery-related compounds: analysis of inorganic SEI phases and a methodology for charge correction. ACS Applied Energy Materials 2018, 1, 4493. 